\title{
ON THE PUBLIC INTIMACY OF THE NEW ORDER: IMAGES OF WOMEN IN THE POPULAR INDONESIAN PRINT MEDIA
}

\section{Suzanne Brenner*}

... [I]t indeed appears that 1959 will be a very important year for all aspects of life in our society, including household matters, which in the past were always seen as trivial, receiving little attention either from the people themselves or from the Government. The revolutionary spirit that pervades all of society should also touch the affairs of the household, which must be improved in a revolutionary manner as well. In this way we will be able to take steps toward improving family life and achieving the goals of the People, to have a Nation that is just and prosperous. ${ }^{1}$

This passage appeared in the magazine Trisula (Trident), styling itself in bold letters as Madjalah Untuk Wanita Berdjoang - the Magazine for Women Fighting [for the

\footnotetext{
* I am grateful to Benedict Anderson, F. G. Bailey, Deborah Homsher, Tanya Luhrmann, Michael Meeker, Melford Spiro, Mary Steedly, and Anna Tsing for reading and commenting on earlier versions of this paper. ${ }^{1}$ S. Kartowijono, "Mari Bantulah Pekan Rumah Tangga!" (Let's Help with Household Week!), Trisula 9,4 (April 1959), p. 7. Emphasis in original. The original reads: "Sdr2.,nampaknya memang tahun 1959 merupakan tahun jang sangat penting bagi seluruh segi kehidupan masjarakat, termasuk urusan rumah tangga, jang dahulu selalu dipandang soal jang réméh, jang kurang mendapat perhatian, baik dari masjarakat sendiri, maupun dari pada Pemerintah. Semangat revolusioner jang meliputi seluruh masjarakat hendaknja djuga menjentuh urusan rumah tangga, jang harus diperbaiki setjara revolusioner pula. Dengan demikian dapat kita melangkah kearah perbaikan kehidupan keluarga dan tertjapailah tjita2 Bangsa, jaitu memiliki Negara jang adil dan makmur."
} 
14 Suzanne Brenner

Revolution]. ${ }^{2}$ Set amid cheerful ads for Blue Band margarine, Pepsodent toothpaste, and cod-liver oil, the articles in this issue of Trisula range from strong pleas to "Return to the Spirit of the 1945 Struggle" (Kembali ke Semangat perdjoangan 1945), echoing the contemporary rhetoric of the Sukarno regime, to a discussion of Home Economics instruction in the United States and a column on hairstyling. An editorial in the next issue (May 1959) sharply criticizes the Legislative Assembly (DPR) for failing to pass the much-debated and anticipated Marriage Laws (Undang-Undang Perkawinan); the writer sees this failure as "a clear example of how our Legislative Assembly is now unable to accommodate the will of the people [satu tjontoh jang djelas betapa D. P. R. kita sekarang kurang mampu menampung kehendak rakjat] by giving satisfaction to the aspirations that have long been held by women." 3 Should Trisula's readers seek diversion from political matters, however, they could easily turn to articles with titles like "Still Beautiful at an Advanced Age" (p. 28) and "Panel Discussion about Family Happiness." (p. 31)

From a post-New Order perspective, this juxtaposition of political rhetoric and criticism with tips on running the household and personal grooming looks quite odd. Far from urging women to engage in political struggle, the popular women's magazines of the New Order period reinforced the Suharto regime's unceasing efforts to create an image of a stable, harmonious, prosperous society built on a foundation of moral, apolitical, middle-class families. The warlike image evoked by the three-pronged spear, trisula, was replaced by softer, more feminine images of womanhood. Calls for politicians to heed the will of the people, and for the people to continue the revolution both in and outside their own homes, were conspicuously absent in the pages of such popular New Order magazines as Femina, Kartini, and Sarinah. The New Order family, like the government party Golkar, was portrayed not as a political entity but as a functional unit, a part of the national whole, that was entrusted with guarding the security, morality, and well-being of its members and of the nation at large.

The resolutely apolitical tone of these magazines, however, merely disguises the extent to which the state relied on the ideological control of women and the familythe two almost always being linked in popular and state discourse-as one of the keys to implementing its social, economic, and ultimately political, agendas. I am not arguing that popular magazines in the New Order existed solely to spread government propaganda, or that the state was the only party involved in promoting conservative agendas for women and families. I would suggest, however, that the policies and practices of the New Order regime set the tone for what could or could not be saidand even what should be said-in print as well as in other forms of mass media, and that this shaped the images of women and the family that were disseminated to the Indonesian public.

\footnotetext{
2 Trisula was published by PERWARI (Persatuan Wanita Republik Indonesia, or Organization of Indonesian Women). According to Sukanti Suryochondro, PERWARI was created in 1945 when two earlier women's organizations, WANI (Wanita Indonesia) and PERWANI (Persatuan Wanita Indonesia) combined with the goal of creating an association dedicated to social justice and humanitarianism. Sukanti Suryochondro, "Timbulnya dan Perkembangan Gerakan Wanita di Indonesia" (The emergence and development of women's movements in Indonesia), in Kajian Wanita dalam Pembangunan (Studies on Women in Development), ed. T. O. Ihromi (Jakarta: Yayasan Obor Indonesia, 1995), p. 46.

${ }^{3}$ Trisula 9,5, p. 5 .
} 
In recent years feminist scholars have paid considerable attention to the New Order state's gender ideologies and policies for women, their social and political implications, and the ways in which they influenced public representations of women, including the portrayal of women and gender relations in the mass media. In her article "Gender Discourse on Television," for instance, Saraswati Sunindyo asserts that the state-owned television network TVRI (Televisi Republik Indonesia) promoted the conservative gender ideologies of the New Order regime. ${ }^{4}$ These ideologies, she believes, strengthened patriarchy in Indonesian society and reinforced the idea that a woman's primary roles are domestic ones. She cites the Panca Dharma Wanita, or five duties of women, that were repeatedly propagated through state-run women's organizations: "According to these, a wife's role is to support her husband, provide offspring, care for and rear the children, be a good housekeeper, and be the guardian of the community." 5 The impact of these precepts was enhanced by the cinetron, or television dramas, produced and aired by TVRI, which functioned as part of the state's ideological apparatus. ${ }^{6}$ Similarly, in "The State and Sexuality in New Order Indonesia," Julia Suryakusuma highlights the regime's efforts to foster what she calls "'State Ibuism,' which defines women as appendages of their husbands and casts female dependency as ideal."7 She, too, sees the government-run women's organizations as having played a key role in the promulgation of this ideology, particularly Dharma Wanita (Women's Duty, a large organization for the wives of civil servants) and the village- and neighborhood-based PKK (Pembinaan Kesejahteraan Keluarga, or Family Welfare Guidance). State Ibuism, she maintains, "is part and parcel of the bureaucratic state's effort to exercise control over Indonesian society." 8

While it is more difficult to document the impact of the state's gender ideologies on forms of mass media and other social domains not directly controlled by the government, there is broad agreement among scholars who have studied the representation of women in the media and elsewhere that the New Order state's policies toward women had a marked influence on public discourses surrounding women and gender. ${ }^{9}$ Even if the state did not go so far as to dictate how women could be portrayed in the media, its messages linking good citizenship for women to good domestic qualities were omnipresent.

A close reading of the popular print media reveals a good deal about how women and the family became the focus of national narratives of development and modernization in the New Order, as well as of persistent anxieties underlying those

\footnotetext{
4 Saraswati Sunindyo, "Gender Discourse on Television," in Culture and Society in New Order Indonesia, ed. Virginia Matheson Hooker (Kuala Lumpur: Oxford University Press, 1993), pp. 134-48. TVRI, she notes, was the only television network operating in the country until 1989.

5 Ibid., p. 135.

6 Ibid., p. 134.

7 Julia Suryakusuma, "The State and Sexuality in New Order Indonesia," in Fantasizing the Feminine in Indonesia, ed. Laurie J. Sears (Durham, NC: Duke University Press, 1996), p. 98.

8 Ibid., p. 102.

${ }^{9}$ Other discussions of this issue are found, for example, in Saraswati Sunindyo, "Murder, Gender, and the Media: Sexualizing Politics and Violence," in Sears, ed., Fantasizing the Feminine in Indonesia, pp. 120-39, and in Diane Wolf, Factory Daughters: Gender, Household Dynamics, and Rural Industrialization in Java (Berkeley: University of California Press, 1992).
} 
narratives. This link between narratives of nation-building and the family was not new; one sees that connection being made, for example, in the passage from Trisula quoted at the beginning of this article. What distinguished the New Order from the preceding era, though, was the extent to which the concern with the intimate sphere of the family came to replace an active politics of the public sphere-a point to which I will return later. The affairs of the family, moreover, were increasingly redefined as public rather than private matters, making the family itself the ground upon which ideological contests over the nation's future were waged.

My aim in this article is to explore how representations of women and the family in the popular print media of the New Order were deployed in the ongoing struggle to define the nation's identity and agendas for modernization (or "development" [pembangunan], the preferred buzzword of the state). ${ }^{10}$ The rapid pace of social and economic transformation during the thirty-plus years of the Suharto regime turned the mass media into a central arena for the display of changing lifestyles and debate over various possibilities for the nation's future. Through the media, the often conflicting forces at play in Indonesian society during this period were packaged for mass consumption; these include the rise of capitalism and consumerism, globalization, Islamization, bureaucratization, and the penetration of the state into almost all areas of social life. I wish to focus here on an aspect of the print media that I have found to be especially revealing of the tensions, uncertainties, and ideological contestations that permeated Indonesian society from the New Order's inception in the mid-1960s through its recent demise (and which continue today): the representation of the imagined transition from "tradition" to "modernity," especially as it is depicted through the figures of women and the family.

As Rita Felski writes,

Accounts of the modern age ... typically achieve some kind of formal coherence by dramatizing and personifying historical processes; individual or collective human subjects are endowed with symbolic importance as exemplary bearers of temporal meaning. Whether these subjects are presumed to be male or female has important consequences for the kind of narrative that unfolds. ${ }^{11}$

I will propose here that images of women more than men have been used to signify the transition from tradition to modernity, and that this has its own significance in the Indonesian context. ${ }^{12}$

\section{A World of all Choices}

The period since the early 1970s has witnessed an explosion of the print media in Indonesia. The rise in the publication and consumption of print media during the New

\footnotetext{
10 On the ideological importance of the mass media and the apparatuses of the state for creating an Indonesian national culture, see Keith Foulcher, "The Construction of an Indonesian National Culture: Patterns of Hegemony and Resistance," in State and Civil Society in Indonesia, ed. Arief Budiman (Clayton: Monash University Centre of Southeast Asian Studies, 1990), pp. 301-20.

11 Rita Felski, The Gender of Modernity (Cambridge: Harvard University Press, 1995), p. 1.

12 Although I am concentrating on media published during the New Order, throughout this article I will use the present tense to refer to general features of these publications.
} 
Order period was fostered by increased literacy rates, ${ }^{13}$ by the growing importance of the mass media in daily life, ${ }^{14}$ and by the expansion of a middle class with the financial means to purchase these publications, which can be quite expensive by local standards. ${ }^{15}$ In representing the Indonesian nation to itself, the popular print media reveal a public fascination with the question of what it means to be modern, and whether or not Indonesians are on the right path toward the right kind of modernity. Popular magazines, tabloids, newspapers, and books offer diverse possibilities for modernity to consumers in easily digestible form. At the same time, the proliferation of choices has propelled the print media's own expansion, for there appears to be an unquenchable thirst in Indonesia for information regarding the latest trends developing both domestically and abroad.

Although the print media target a readership consisting of both women and men, it is the images of women that stand out in their diversity. Photographic and textual images of women, more than those of men, serve as symbolic representations of a burgeoning consumer culture; of the growing Islamic movement; or of the moral deficits of modern society. Women not only participate fully in the processes of social change that Indonesia is undergoing, they also signify those processes. Popular periodicals and books bombard their readers with a barrage of visual and verbal images of "the modern Indonesian woman" in her many incarnations: as happy consumer-housewife, devoted follower of Islam, successful career woman, model citizen of the nation-state, and alluring sex symbol. Taken together, these images offer women a bewildering array of lifestyle possibilities, many of them touted as the ideal for the enlightened modern woman as she emerges from the narrow confines of traditional society. ${ }^{16}$ To an extent

13 According to one source, the percentage of Indonesians age fifteen and older who could read and write in 1997 was 83.8 percent (89.6 percent of males and 78 percent of females). Source: Central Intelligence Agency, The World Factbook 1998.

14 The Central Bureau of Statistics (Badan Pusat Statistik) of the Republic of Indonesia indicates that the percentage of the Indonesian population age ten years and older who read newspapers and/or magazines in 1997 was 22.83 percent. 59.17 percent were said to listen to radio and 78.22 percent to watch television. Source: Badan Pusat Statistik Home Page, statistical information on "Access to Mass Media."

15 In late summer 1996, for instance, an average magazine (e.g., Kartini, Amanah, Tiras, or Popular) cost between Rp 5000 and $R p$ 7000, or around two US dollars-more than some workers earned for an entire day's work. The brisk trade in second-hand magazines, however, makes them available to some people who might not be able to afford them new.

16 The preoccupation with modernity is not a recent phenomenon in Indonesia; the vision of Indonesian society standing at the threshold of a modern era has been a dominant motif since the early twentieth century. Benedict Anderson has noted, for example, that a significant number of Indonesian newspapers and periodicals from the first quarter of this century contain in their titles words suggesting radiant light--sun, flame, torch, or dawn, for example-symbolizing a transition from the darkness and ignorance of the past to the brightness and full wakefulness of a new era. Benedict Anderson, "A Time of Darkness and a Time of Light: Transposition in Early Indonesian Nationalist Thought," in B. Anderson, Language and Power: Exploring Political Cultures in Indonesia (Ithaca: Cornell University Press, 1990), p. 243, esp. fn. 6. It was at this time as well, as Kenji Tsuchiya points out, that the Dutch word modern began to be used widely among nationalist leaders and young people to express the concept of a better future for the colonized people of the Indies. Kenji Tsuchiya, "Javanology and the Age of Ranggawarsita: An Introduction to Nineteenth-Century Javanese Culture," in Reading Southeast Asia, ed. Takashi Shiraishi (Ithaca: Cornell Southeast Asia Program, 1990), p. 76. One of these people was Raden Adjeng Kartini (1879-1904), the young Javanese aristocrat who eventually earned a reputation, based on her posthumously published letters, as an early Indonesian nationalist and feminist. Drawing on her Dutch education and exposure to liberal Dutch ideas, Kartini wrote at the turn of the century (in Dutch) of her fervent dreams for a new, modern society. The 
unprecedented in Indonesian history, New Order women-especially middle- and upper-class, urban women-were presented with choices from among various "modern" lifestyles, sometimes sharply contrasting with each other. These choices were not just seen as individual choices, but as choices that would have a bearing on the very future of Indonesian society.

One might argue, in fact, that the perception of these multiple options constitutes one of the essential features of "modernity" itself. While the concept encodes a variety of meanings both within and across national boundaries, 17 modernity tends to be conceived of, particularly in societies whose members are not quite certain of having fully attained the status of "modern," as a juncture at which the conventions and restrictions of traditional society give way to a vast new world of possibilities for living. Inherent in the idea of modernity is a break with tradition-the belief that the course of the future is not contained in the received wisdom or practices of the past, but must be forged through deliberate, self-reflective, and perhaps unprecedented choices and actions taken in the present. ${ }^{18}$

I take modernity, like tradition, less as an empirical given than as a trope that is shaped by specific historical and political circumstances. If "tradition" is a convenient figure that stands for the comforts as well as the constraints of a way of life handed down (or at least imagined to have been handed down) from past generations, then "modernity" denotes a way of life that brings with it both the luxuries and burdens of having to choose new avenues for living. As ideologies, the tropes of tradition and modernity constantly play off one another. When tradition is glorified, modernity is depicted as a threat to the sanctity, stability, and safety of the old ways. When modernity is glorified, it is portrayed as the welcome antidote to the stifling grip of past generations on the present. In the politics of representation, these conceptions of modernity and tradition may be invoked to support either conservative agendas or demands for change-or, quite frequently, a combination of both, as one sees in the Suharto regime's perpetual push for modernization at the same time that it sought legitimacy and social and political stability in a reconstructed tradition. The manipulation of the figures of tradition and modernity is all the more potent when a society envisions itself, collectively and self-consciously, as standing poised at the threshold of modernity, with one foot through the door. One cannot go back, yet to go

imagery of the darkness of tradition giving way to the light of modernity is very much present in Kartini's correspondence. See Joost Coté, trans., Letters from Kartini: An Indonesian Feminist, 1900-1904 (Clayton: Monash University Asia Institute, 1992).

17 James Faubion observes that the notion of modernity is vague and fraught with ambiguities; further, he notes that "the task of being and becoming modern is likely to be quite different from one place to the next, and hence that modernity itself is likely to be not one but many things." James Faubion, "Possible Modernities," Cultural Anthropology 3,4 (1988): 374. Lisa Rofel, too, argues that modernity can only be understood in its particular local settings; that "there is no singular transnational standard" for modernity. Lisa Rofel, "Rethinking Modernity: Space and Factory Discipline in China," Cultural Anthropology 7,1 1992): 93-114.

18 The concept of modernity "expresses the conviction that the future has already begun: It is the epoch that lives for the future, that opens itself up to the novelty of the future." Jürgen Habermas, The Philosophical Discourse of Modernity: Twelve Lectures, trans. Frederick G. Lawrence (Cambridge: MIT Press, 1987 ), p. 5. See also Peter Osborne, The Politics of Time: Modernity and Avant-Garde (London: Verso, 1995). 
forward brings the risk of shutting behind one those values and ways of life associated with the comforts and foundations of the past.

The popular media play key roles in defining both the benefits and hazards that modernity presents. They deliberately bring to public consciousness the problems often seen to be engendered by modernity: the decline of morality and of a sense of collective social responsibility; the disintegration of the family; and the replacement of timehonored values supposedly rooted in indigenous cultures with new and potentially dangerous values imported from abroad. On the other hand, mass communications, including print media as well as radio, film, and television, more than anything else are responsible for the dissemination of ideas about the great variety of possibilities that modernity has to offer. ${ }^{19}$ This is exemplified by a two-page, full-color advertisement for a new shopping mall in Jakarta appearing in the popular women's magazine Femina, which includes the bold caption: "Beginning today, a world of all choices is open to you" (Mulai hari ini, dunia segala pilihan terbuka untuk anda). 20 (Another caption, surrounding the inset picture of the mall, says, in English, "A World of Choices.") "Choice" here does not mean the freedom to take moral responsibility for oneself, or liberation from oppressive traditions. It is, instead, the freedom to buy whatever commodities are available at the mall, provided, of course, that one has the financial means to do so.

A comparison of two magazine covers illustrates the diversity of lifestyle choices that are being offered to Indonesian women who wish to be modern. In the first, a slim, attractive young woman sits cross-legged on the floor, posture erect, shoulders raised, hands on hips, in an arrogant but seductive pose. Her arms and shoulders bare, she wears silky black pants and a very low-cut, pale green bodysuit. With thick, glossy red lips sensuously parted, eyebrows tweezed in a steep arch, long black hair blowing back, she stares directly and challengingly at the camera, a hint of scorn on her face. Long rhinestone earrings dangle almost to her collarbone, glittering in the light and adding to her sultry appearance. This photograph is found on the cover of the magazine Tiara: The Magazine of Behavioral Trends and Information (Tiara: Majalah Trend $\mathcal{E}$ Informasi Perilaku), which has an upbeat, decidedly Westernized flavor to it, featuring articles like "The Gay Lifestyle: The Way of Our Middle Class?", "The Pluses and Minuses of Marrying a Divorced Man," and "Rodeo Drive: Elite Shopping District of Los Angeles."21

\footnotetext{
${ }^{19}$ In his book on Indonesian cinema, for example, Karl Heider discusses the various "models for modernization" that are presented in popular Indonesian films. Certain stylized themes and conflicts are repeatedly introduced into films to represent the dilemmas presented by modernization. A central problem that these films focus on, as Heider sees it, is "how to modernize and yet retain Indonesian identity; how to avoid the perils of excessive conservatism on the one hand and destructive Western-ness on the other." Karl Heider, Indonesian Cinema: National Culture on Screen (Honolulu: University of Hawaii Press, 1991), p. 86.

${ }^{20}$ Femina 21,8 (February 25 - March 3, 1993). This ad for CitraLand Mall includes pictures of a man in a fashionable suit opening a bottle of champagne; an expensive-looking stereo/VCR system; two smiling women wearing very short skirts and enjoying a drink and conversation in a restaurant; leather handbags and shoes; a chic woman in a well-accessorized outfit; men's dress shirts and ties; a little girl happily holding a large stuffed animal; and a picture of the front of the modern-looking mall, which has a McDonald's sign displayed prominently on it. Although the people pictured in the ad are Indonesian, the images evoke visions of an American-style consumer paradise.

21 Tiara 72 (February 13-27, 1993).
} 
In the second photograph, a young, intelligent-looking ibu sits with her young son. The two of them are looking intently at a book with Arabic writing on the cover, which they hold together in front of them. The woman wears a long-sleeved, loose, demure blue dress or tunic trimmed with white embroidery, her head, hair, and neck completely covered with close-fitting cap and headscarf in modest Islamic style. She, too, has glossy red lips that are slightly parted-not seductively, however; she seems, rather, to be reading aloud to the boy as he listens raptly. Her only visible jewelry is a wedding ring, although her fingernails are painted red and she wears tasteful but noticeable eye and facial makeup. This picture appears on a 1990 cover of Amanah ("message" or "mandate"), a magazine targeted mainly at middle-class, devout but moderate Muslims. ${ }^{22}$

These magazine covers offer two antithetical visions of modern Indonesian womanhood. The first woman openly displays her sexuality, her self-reliance, her aggressiveness; the second quietly exhibits her Islamic piety and education and her nurturing, motherly qualities. Yet the two pictures also share something in common: each stands as a marked departure from more conventional images of Indonesian women, suggesting its own way of being modern.

The woman in the revealing green bodysuit represents someone who is unquestionably Westernized, blatantly defying common Indonesian standards of "proper" behavior for females. This picture is clearly modeled upon similarly sexualized images of women from the Western mass media, such as one might find on the cover of Cosmopolitan. The photograph of devout Muslim mother and child, in contrast, exalts those standards of morality and propriety for women that the first photo flaunts; it, too, however, stands for a relatively new way of life for Indonesian women. Until the early to mid-1980s, young, urban, educated women, like the woman represented here, did not dress in this Islamic style; almost all wore Western-style clothing. To find such a picture on the cover of a magazine aimed primarily at educated, middle-class readers attests to the growing popularity of the Islamic movement, which offers alternatives to the Westernized, consumer-oriented lifestyle endorsed by Tiara. Despite their obvious differences, then, these two images of women bear witness to the impact of globalization on Indonesian society, for both draw heavily on imported models of how a modern woman should look and behave.

Although both magazines are aimed primarily at middle- to upper-class consumers, their cover images represent competing visions of modernity that seem difficult to reconcile. The first offers an image of modern Western-style "freedoms" freedom to consume, to indulge one's desires, to be assertive and independent, even to defy local standards of morality-while the second presents an image of a modern society built on Islamic values, where families come first, and where women find their fulfillment not in consumerism, nor in the satisfaction of their personal desires, but in motherhood and Islamic piety. While these images are diametrically opposed, it is probably safe to assume that for many Indonesian women the search for a modern identity is far more complicated than either image suggests and the messages that they receive through the media far less clear.

22 Amanah 116 (December 14-27, 1990). Although Amanah is not strictly a women's magazine, its cover photographs are almost always of women, and it includes features (recipes, fashion, etc.) that are aimed at a female audience. 
A more recent (August 1996) cover photo from Amanah, in fact, almost seems to meld together the earlier images from Tiara and Amanah in a remarkable sexualization of Islamic womanhood. ${ }^{23}$ Here, a stunning model in her early twenties wearing heavy makeup, rather gaudy costume jewelry, and a white dress or tunic studded with white and gold beads stares directly at the observer from beneath a gauzy white scarf draped loosely over her head. Her hair, ears, and neck are all visible. Shiny red lips open in a slight pout, the arch of her tweezed eyebrows penciled in, she seems to be parting her headscarf in a revealing gesture, as if she is about to remove it -the overall effect can perhaps best be described as a "come hither" look. The provocative pose of this model appears to lend support (unintentionally, one would presume) to one of the feature articles: "The Muslim Community Has Not Yet Become a Moral Force" (Umat Islam Belum Jadi Kekuatan Moral). However, as if to reassure the reader that she is a suitable cover model for a magazine aimed at "families of hajis and [other] Indonesian Muslims" (Bacaan Keluarga Haji \& Muslim Indonesia), a profile of this fashion model inside the magazine, with another rather seductive-looking photograph, bears the caption "Caroline always remembers God" (Caroline Selalu Ingat Allah).

To my mind, the apparently unproblematic blending of Muslim purity and Western sexuality in a single image perfectly captures the contradictory messages and interests of the late Suharto era; it is quintessentially New Order. The image is even presented as a "national" one: the background behind the model's photograph consists of a drawing of the red-and-white Indonesian flag in honor of Independence Day that month. One sees in the image the demands of New Order capitalism and the desire of Amanah's publishers to make money by selling more copies at the newsstand-Amanah had by 1996 become a very slick magazine with ads for instant coffee ("Tastes good black or white"), wristwatches ("Fashion in Time"), and travel agencies offering deluxe packages for the haj costing upward of US $\$ 6,000$. The heightened sexuality of Amanah's cover image is common to other magazines in that period; a casual survey of Femina, for instance, shows a distinct movement from innocent-looking cover images in the mid 1970s (of mothers, young girls, models, or movie stars in demure attire, often gazing dreamily off in the distance or smiling sweetly at the camera) toward far more provocative, sexy poses in the 1990s. The growth of the Islamic movement from the early 1980s on, it seems, did not curtail the influence of the Western mass media in Indonesia. One also sees in the later Amanah cover the degree to which at least some segment of the Islamic movement had been tamed and "mainstreamed" by that time, presenting itself, in effect, as just another middle-class lifestyle with its own glossy magazines, glamorous cover models, and fashion industry. ${ }^{24}$

The mass media capitalized upon and contributed to the contradictions that marked the New Order period. Behind the choices for modernity offered to Indonesians through the media has been a persistent public anxiety about the

\footnotetext{
23 Amanah 11,9 (August 1996).

24 By August 1996, Amanah had done away with its columns that required readers to have a better-thanaverage knowledge of Islam (such as those on Islamic doctrine or poetry), replacing them with regional reports and full-color spreads on cooking and Islamic fashions, among other things. See ibid., p. 11, for the editor's explanation of the reason for eliminating the "heavier" religiously oriented columns in favor of lighter features: "Our consideration was that the target audience that we are aiming at is the upper-middle class whose understanding of religion is still just barely adequate" (. . kalangan menengah atas yang tingkat pemahaman keagamaannya masih pas-pasan).
} 
implications of those choices for the future of the society. While there seems to be general agreement that modern technology and education are beneficial and desirable, in some conservative public discourse Western-style modernity has been associated with the dangers of extreme individualism, loose morality, and secularism. Government officials and religious leaders have often warned the Indonesian people to borrow selectively from the West-that is, not to import the bad with the good. Modernity may offer a multitude of choices, but some of those choices are not "suitable" for Indonesia, they have declared. The rising influence of the Islamic movement has added particular force to these views; some of its followers believe that Indonesians belong to the global ranks of Muslim peoples who have been victimized by Western imperialism, pointing to examples of other Islamic countries for alternatives to Western-style modernity.

Much of the public angst over modernization has focused directly or indirectly on women, suggesting that women's attitudes and behavior are considered crucial in determining the course that Indonesian modernity will take. Women's sexuality, domestic life, and work life all serve as arenas in which symbolic battles over modernity are waged; a close look at popular images of women helps to illuminate how and why these seemingly personal dimensions of women's lives are the objects of so much public concern.

Why are women, more than men, viewed as the harbingers of the future of Indonesian society? As tradition and modernity are conceptualized, women tend to be identified as the keepers of tradition and the guardians of those institutions, domains, values, and practices that are most closely linked to tradition. ${ }^{25}$ This does not confine them conceptually to the past, however, because their duty is to maintain continuity with the imagined moral values of the ancestral past and to transmit them to future generations. Particularly in their role as mothers, they are considered to hold the moral fate of the nation in their hands. In contrast, men are typically envisioned as the pioneers of the economic, political, and social innovations associated with modernization; they are not burdened with the moral baggage of the past to the extent that women are. This places the weight of maintaining "traditional values" on women's shoulders, even as they are enjoined not to hamper the nation's progress toward modernity through excessive conservatism. As active citizens of the state and major contributors to the Indonesian economy, New Order women were encouraged to

\footnotetext{
25 Many authors writing about countries besides Indonesia have also noted the association of women with tradition under otherwise modernizing conditions. One example is Ketu Katrak, who notes that in India, the idea that women are the guardians of tradition has served to reify some of the most regressive aspects of tradition and to reinforce an essentialized vision of womanhood. Ketu Katrak, "Indian Nationalism, Gandhian 'Satyagraha,' and Representations of Female Sexuality," in Nationalisms and Sexualities, ed. Andrew Parker, Mary Russo, Doris Sommer, and Patricia Yaeger (New York: Routledge, 1992), pp. 395406. In an intriguing study of the gendered aesthetics associated with modernization in Europe and the United States from 1830 through the 1980s, Penny Sparke observes that "Entering into and assimilating modernity was ... for women, a much more gradual experience [than for men] for one of their duties in the era of modernisation was to act as guardians of the past, maintaining a sense of continuity by keeping one foot in the pre-industrial world. In this way they provided an anchor to ensure that modernity was encountered with a set of values that was both tried and tested. The inevitable conservatism that accompanied that role created an 'archaic' version of modernity which became associated exclusively with women for well over a century. " Penny Sparke, As Long as It's Pink: The Sexual Politics of Taste (London: Harper Collins, 1995), pp. 4-5.
} 
participate in the government's campaign to promote development, but only in ways that would not interfere with the stability of the family or their roles as the guardians of morality and tradition. When women behave in ways that are not in keeping with their assigned role as the guardians of traditional norms, this is seen to bode ill for the future of the society.

Public discussions about the erosion of morality often imply that women have failed to do their part in protecting the sacred values of the past from the onslaught of the present. The most common figure for the decline of morality, simultaneously seen as the primary cause for and result of that decline, is the breakdown of the family. This breakdown, in turn, is frequently attributed to women's rejection of their proper roles as wives and mothers. This is not to say that public discourse denies women the right to work outside the home or to occupy other roles besides those of wife and mother; Indonesian women, like women elsewhere in Southeast Asia, have been economically and socially active outside the home since early recorded history, ${ }^{26}$ and there is no across-the-board insistence that women confine themselves exclusively to the domestic domain. It would be more accurate to say that women are broadly expected, regardless of their activities outside the home, to put the welfare of the family above all else, provided that this does not interfere with the goals of state and society.

\section{Dilemmas of the Karier Woman}

One of the challenges faced by Indonesian women today, as presented by the mass media, is to be a modern woman without compromising the integrity of the family or one's essential nature (kodrat) as a woman. The choices that modernity offers to women pose their own risks in this regard, as the media make clear. One of the issues that was raised again and again in New Order magazines, especially those geared toward women, focused on the quandaries of the "Career Woman" (wanita karier). A seminar was sponsored in May 1991 by the women's magazine Kartini, for example, on "The Successes and Problems of the Career Woman (Dilemmas of the Modern Era)" (Sukses dan Problematika Wanita Karier [Dilema dalam Era Modern]). ${ }^{27}$ An advertisement for the seminar that ran in Amanah read:

In a society that is rapidly moving forward, various issues emerge at life's threshold and become problems that require our collective attention. One of them is the appearance of the career woman, who until now remains the subject of debate. ... This is a big advancement, a rapid evolution.

On the other hand, the challenges aren't minor: their dual roles as housewives and workers, challenges from their husbands or other relatives, and, just as

\footnotetext{
${ }^{26}$ In a survey of Southeast Asian society from the mid-fifteenth through the late seventeenth centuries, Anthony Reid writes that in parts of Indonesia as well as elsewhere in the region, women often worked as farmers, traders, artisans, and entertainers in this period; others served as soldiers, court retainers, and political envoys. Anthony Reid, Southeast Asia in the Age of Commerce, 1450-1680. Vol. 1, The Land below the Winds (New Haven: Yale University Press, 1988), pp. 162-72.

${ }^{27}$ Note the heavy use of English loanwords in the Indonesian title, suggesting that the topic is one that is closely associated with Western versions of modernity.
} 
important, the temptation to become involved in extramarital affairs. This has become the subject of gossip in certain circles. But is this really how things are?28

The term wanita karier, like the English "career woman," does not simply refer to a woman who engages in productive activities outside the home. A woman who earns money through types of work that have traditionally been identified as women's work (or both women's and men's) in various parts of Indonesia-farming, craft production, or trading in the marketplace, for instance-is usually not considered a "career woman," no matter how much money she earns through her trade. Nor does a factory worker or a waitress qualify as wanita karier. Since working outside the home is nothing new for Indonesian women, nor does it ordinarily carry the stigma for them that it does for women in some other parts of the Islamic world, ${ }^{29}$ the notion that this is both "a big advancement" and a "subject of debate" implies that the term "career woman" has special connotations. A career woman is someone who does white-collar work in the "modern" sectors of the economy. She may work as a business executive, a secretary, a lawyer, or a civil servant, among other professions. What distinguishes her from other women in the workforce is that she puts her energies into forms of work that are identified as modern, professional, generally urban, and, in some cases, typically masculine. She is thus a woman with some power-power that is independent of her status as wife or mother, and which establishes her place in a sector of society that is removed from the constraints of "tradition." "Career woman," in short, is an imported concept that carries with it both the positive and negative associations of Westernization.

As in English as well, there is no male equivalent of "career woman," no specially marked category of "career man" to designate men who work in the modern sector. In modern Indonesian society, there is nothing remarkable or problematic about a man who works as a professional. A career woman, however, while generally admired for her successful entry into the modern world, is also seen as a potential problem for her family and for society. This is apparent from the controversy over career women cited in the ad for the seminar on wanita karier: her role as career woman may come into conflict with her duties as wife and mother. She may become too absorbed with her work, at the expense of time and energy that ought to be spent on her family. Worse, her independent lifestyle might lead her into extramarital liaisons that could result in the breakup of her marriage and family. The fear here is that she will become too much like the stereotyped Western woman-self-absorbed, overly obsessed with her career (and thus too much like a man), and, most threatening of all, rampantly sexual outside the bonds of matrimony.

Women are expected to be, above all, the nurturers of their families and the bastions of domestic life, and they should not let their careers interfere significantly with these functions, according to the popular media. Becoming a successful corporate executive or a high-ranking government official does not abrogate a woman's responsibilities in this regard. Similar anxieties are almost never directed toward men, because men are expected to be, first and foremost, providers rather than nurturers for

\footnotetext{
28 Amanah 126,3 (May 3-16, 1991).

${ }^{29}$ For a detailed discussion of the hardships faced by working women in Cairo, for example, see Arlene MacLeod, Accommodating Protest: Working Women, the New Veiling, and Change in Cairo (New York: Columbia University Press, 1991).
} 
their families and, at the same time, pillars of economic development, both roles being fully compatible with professional careers.

The popular print media, especially women's magazines, are full of articles, letters, and stories about wanita karier-both those who are seen as successes, happily balancing career and family life, as well as those who, it is suggested, have "gone too far" with their careers. Large-print teasers on the front of magazines entice buyers with phrases like "Involved in Love at the Office" (Terlibat Asmara di Kantor, Femina 22,40, October 3-10, 1994); "Career Women Troubled by Stress" (Wanita Karier Rawan Stres, Sarinah 277, May 31 -June 13, 1993); "Men at the Office: Friends or Foes?" (Pria di Kantor Kawan atau Lawan, Femina 19,17, May 2-8, 1991); and "Career Woman Go Home" (Wanita Karier Pulanglah, Amanah 203, 18 April 18 - May 1, 1994). It is notable that the only one of these that actually tells career women to "go home" comes from a magazine with an Islamic bent; the most insistent calls for women to leave the workplace have come from conservative Islamic factions, even though many Indonesian Muslims, including devout ones, feel that it is acceptable for women to work. However, even secular magazines like Femina that offer handy tips to professional women about how to improve their careers prey upon (and help create, no doubt) the nagging anxieties of their readers about the perils of being a career woman.

Such fears are not raised only in women's magazines; they are also common in newspapers and other media. An article in the Jakarta daily Kompas covering the seminar on "The Successes and Problems of the Career Woman" focused almost exclusively on the problems that career women face in their marriages as a result of the affairs that they have, or are assumed to have. ${ }^{30}$ According to the newspaper, one of the discussants at the seminar, Emha Ainun Nadjib (a prominent Muslim writer and intellectual), expressed his concern that the social, cultural, and moral controls that might keep such affairs in check were becoming more fragile as society becomes more modern. Another speaker commented that such affairs violate the vows of marriage, and that "At the heart of an affair is a dishonest attitude and a lack of respect for one's husband, family, and religion."

A short story that was printed in Femina in 1993, titled simply "Old-Fashioned" (Kuno), highlights in caricature the problems that career women are said to face. It begins with the bold-faced caption: "Debby, had become aware too late that Adam, her husband, was an old-fashioned type of man who wanted his wife to devote herself fully to her family. Meanwhile, her career was now quite good."31 The accompanying illustration is of an attractive but tired and perturbed-looking woman, her long hair rather disheveled, resting her head heavily against her hand. Floating abstractly behind her are many rupiah bills and a family photograph, its glass frame in the process of shattering.

Debby (whose name already identifies her as someone with Western tendencies) is a professional secretary. The story starts with her husband demanding to know, as he

30 "Potensi dan Tantangan bagi Wanita Karir" (Possibilities and Challenges for Career Women). Kompas, May 19, 1991 (page number not available). I am grateful to the Institute for the Study and Development of Women and Children (Lembaga Studi dan Pengembangan Perempuan dan Anak) in Yogyakarta for making a copy of this article available to me from their files.

31 Helyanti, "Kuno" (Old-fashioned) Femina 21,8 (February 25 - March 3, 1993), p. 64. 
picks her up from work, why she "always has to go everywhere with her [male] boss." 32 An argument ensues (the first of many in the story), as Debby, tired from a long day of work, becomes irritated with Adam for his jealousy and his unwillingness to accept her professional responsibilities as a secretary. Later in the story, Adam complains that Debby's skirt is too tight to wear to work, and warns her, for the sake of her family, to behave properly, as a secretary with a family should behave. "Affairs between bosses and secretaries have become a kind of tradition" (Affair antara bos dan sekretaris sudah menjadi semacam tradisi), he comments, explaining to her why his jealousy is justified. "Just having a family isn't enough to guarantee that an affair won't happen." 33 Annoyed by Adam's attitude, Debby tells him angrily one day that he should see a psychologist. Adam replies:

"I'm your husband, Deb. What kind of a wife accuses her husband of being mentally ill, let alone tells him to see a psychologist! You're a strange wife!"

Debby held back her tears.

"You're too full of yourself, Deb! You're too proud of your profession. Of your career. I know, you have a good career, you make a lot of money. But what kind of a man wants his own wife to openly compete with him?"34

The climax of the story occurs when Debby and Adam's two young children witness an argument between them and beg their mother tearfully not to make their father angry, for fear that it will cause the breakup of their marriage. Wistfully, Debby recalls the happier days of her marriage. Slowly, it dawns upon her:

It turned out that Adam was a conventional type of man. An old-fashioned man with a modern appearance. He wanted a wife who would dedicate one hundred percent of her life to her family. Meanwhile, all that she had understood from Adam until now were his excessive feelings of suspicion and jealousy, which she had harshly regarded as psychological problems. Of course this must have been painful for Adam. A man of that type would be tortured if he lived with a wife who had an active career [istri yang aktif berkarier].

Was Adam wrong? No, he wasn't wrong. He was the product of his environment, which had shaped and carved him into a conventional human being [manusia konvensional] and I was too late in realizing it. ${ }^{35}$ When Adam gave me permission to work, it was surely with a heavy heart, and not of his free will. At that time he was faced with the fact that the cost of running a household wasn't small. Especially when the children came along. After they had sat down and figured it out, it turned out that Adam's income alone wasn't enough. When he (reluctantly) gave Debby permission to work and it turned out that his income was much smaller than hers, he was forced to accept the situation as it was. But that was two years ago. Now things were very different. Who should change? Who should make a sacrifice?

\footnotetext{
32 Ibid.

33 Ibid., p. 65.

34 Ibid., p. 65.

35 The sudden shift from the third person to the first person, and then back again, occurs in the original Indonesian text.
} 
Debby became aware for the first time that her feelings of love for her family were greater than her own personal interests. The fact was that she was terribly afraid imagining that these arguments might be the start of the breakup of her family. She didn't have the courage to hold on to her career, which she had built up from null. For in the past, her motivation to work had only been to help support the family financially. Not more than that. This was the answer to all of her questions. 36

Finally, Debby makes peace with herself and with Adam. First, though, Adam tells her that he has been to a (female) psychologist, who informed him that, according to her analysis, he is old-fashioned. Smiling, Debby tells Adam:

"I know, 'Dam, that I have an old-fashioned husband. It would be a shame to waste him. An antique is valuable, you know. So I'm going to stay at home and take care of him!"37

The story ends with Debby sweetly assuring Adam that she will leave her job, provided that Adam will help her think of ways to occupy her time at home. Adam, of course, is pleased as punch:

Adam gaped in astonishment, but a moment later his eyes shone with delight. He hugged Debby tightly and kissed his wife's face. "Don't worry, Deb! My brain is still sharp enough to come up with ideas!" he promised. ${ }^{38}$

It is a happy ending. The moral of the story is not that Debby had been wrong to pursue a career in the first place, especially given that she had done so for the economic well-being of her family. The problem was that she had selfishly taken her career too far, pursuing it at the expense of her family's happiness. The burden was not on her "old-fashioned" husband to change, but on her to adjust herself to his needs and the needs of the whole family. Debby was in danger of becoming too much like a Western woman-wearing tight skirts to work, accompanying her male employer everywhere, paying too little attention to her family, threatening to take a taxi home from work when her husband made her angry, telling her husband to see a psychologist, and, by earning more than her husband, wearing the proverbial pants in the family. ${ }^{39}$ She redeems herself in the end by returning to the role of emotional nurturer of her family and by acceding to her husband's wishes that she be a dedicated wife and mother rather than a career woman.

\footnotetext{
36 Ibid., pp. 66, 105.

37 Ibid., p. 105.

38 Ibid., p. 105.

${ }^{39}$ It is not unusual for Indonesian women to earn more than their husbands. In the Javanese court centers of Solo and Yogyakarta, for example, there was a tradition of men working at prestigious but low-paying jobs for the palaces or state bureaucracy while their wives supported the family as batik producers or traders. That the women were earning more than their husbands did not usually pose a problem, since the work done by their husbands was of socially higher status. The difference here is that Debby is working at a white-collar job in the modern sector, like her husband (we assume), but earning more than him-a less acceptable state of affairs, apparently. For more on the gender and status relations of the Javanese merchant class in Solo, see my book The Domestication of Desire: Women, Wealth, and Modernity in Java (Princeton: Princeton University Press, 1998).
} 
The style of language used in this story, which is liberally sprinkled with loanwords like konvensional, tradisi, affair, bos, profesi, nonsens, Mama/Papa, analisis, and komunikasi, conveys a distinctly Westernized, up-to-date flavor. Debby and Adam are portrayed as urban, middle-class Indonesians who have been thoroughly integrated into the modern world. But their family life has become unhappy because Debby has adopted the negative aspects of a modern lifestyle with the positive ones. She is only steps away, it seems, from having an affair with her employer, driving her husband to divorce her, and ruining her children's lives-and her own-as a result. She and her family are saved just in time by her husband's prudent traditional values (balancing her own excessively modern/Westernized ones) and by her own better judgment.

The idea that having a career brings conflict into a woman's life is reiterated elsewhere in Femina. An article called "Self-Development and Women's Anxieties" begins optimistically by stating, "The Kartinis of the 20th century are truly terrific; their accomplishments aren't any less impressive than those of men." 40 The writer quickly goes on, however, to focus on the regrets that career women have at the loss of their "special rights as women." The example given is that of Astri, "a career woman who is successful but who still has anxieties that are unique to women":

With all her successes, Astri suddenly felt that her life was empty. It seemed as if she had lost something ... She felt that her husband wasn't paying enough attention to her. The proof was that he never forbade her to go anywhere, and he never asked her to make him breakfast . . . Astri began to think, maybe it would be better if she stayed at home again, wore a housedress, cooked, prepared her husband's clothes and towels for him, and took her children to ballet lessons, swimming, and so on ...

The truth is, you can be sure that there are many other Astris out there. You yourself, if you want to be honest, also have a hard time freeing yourself from this complex. ${ }^{41}$

In Tiara, "the magazine of behavioral trends and information," another risk of being a career woman is highlighted: that of emasculating one's husband to the point where he is driven into the arms of other women in order to rescue his manhood. An article about why married men keep mistresses, "Understanding Real Men," discusses a case where a man, Ansar, started to feel that his wife was becoming too assertive at home because of her important job as the head of a company:

Tini became extremely independent; her actions were efficient because she was always pressed for time; she was assertive; and she tended to be dominant. She began not to be able to distinguish between situations at the office, which were formal and rational, and the situation at home, which she should have approached more emotionally (warmly, with love, intimately) ... Tini's overly rational attitude made Ansar feel humiliated. ${ }^{42}$

\footnotetext{
40 “Pengembangan Diri dan Kecemasan Wanita" (Self-development and women's anxieties), Femina 21,8 (February 25 - March 3, 1993), p. 24.

41 Ibid.

42 "Memahami Pria-Pria Sejati" (Understanding real men), Tiara 53 (May 24-June 6, 1992), p. 38.
} 
In response to Tini's "rational" (rasional) and domineering (dominan) attitude, Ansar became involved with one of his employees. The author of the article (a manTiara, it should be noted, is not a women's magazine) obviously sympathizes with Ansar; the implication is that Ansar's actions were his wife's fault, not his own. In order for a career woman to remain within the limits of acceptable behavior, she must keep to her proper "female nature" (kodrat wanita) - in other words, regardless of how she behaves at work, at home she must be instinctive and emotional, gentle, caring, and nurturing. ${ }^{43}$ She should leave "rationality" and the final decision-making in the household to her husband. When modernity leads a woman to abandon her essential female nature at home as well as in the workplace, she must be prepared to face the consequences.

The message of these articles is clear. A modern woman has choices, but she needs to choose carefully. If she neglects her "traditional" obligations as wife and mother in order to follow a career, she will pay dearly for it. Modernity comes at a price. ${ }^{44}$

But what other path might the regretful career woman follow? The ideal of the middle-class "housewife" ( $i b u$ rumah tangga) is portrayed as an alternative to the "career woman" in the popular media. However, the concept of the housewife is as much a Western import as that of the career woman. (It is worth noting that in the 1959 Trisula article "Let's Help with Household Week!" the term kaum wanita rumahtangga was apparently still alien enough that the English translation "house-wife" was provided in parentheses for clarification. ${ }^{45}$ What is especially striking about this image is that although it is usually depicted as a return to traditional values in a modern age, it promotes a way of life that is foreign to-and unattainable by-most Indonesian women, who work out of economic necessity as well as by choice. Femina's profile of Astri, the successful career woman who secretly longs to stay at home so that she can cater to her husband and take her children to ballet and swimming lessons, is sheer fantasy for all but a tiny percentage of Indonesia's population, yet the writer confidently tells the anonymous reader that "you can be sure that there are

43 Krishna Sen also writes about kodrat wanita, especially as it is depicted in Indonesian film. As she puts it, "Kodrat implies both the nature and the destiny of women [wanita] and the central element in this seems to be the woman's function as mother, contained within the family sphere. Any movement of the woman beyond this sphere becomes an issue of contention within the dominant discourse of the narrative." Krishna Sen, "Repression and Resistance: Interpretations of the Feminine in New Order Cinema," in Culture and Society in New Order Indonesia, ed. Hooker, p. 117. See also Tineke Hellwig, who remarks in her analysis of two popular Indonesian novels that they "promote motherhood as every woman's prime vocation, and the basis of her status. All the other aspects-being a wife, doing paid work-are subservient to it." Tineke Hellwig, "Rape in Two Indonesian Pop Novels: An Analysis of the Female Image," in Indonesian Women in Focus, ed. Elsbeth Locher-Scholten and Anke Niehof (Dordrecht: Foris Publications, 1987), p. 250.

44 This message is not exclusive to the print media. Scholars studying other forms of popular media have also observed that the career woman is frequently portrayed as an object of suspicion. Heider, for instance, notes that the career woman in Indonesian films is portrayed as an anomaly "which must be resolved through domestication by the end of the film." Karl Heider, Indonesian Cinema, p. 118. Sen, in "Repression and Resistance," also suggests that the reversal of the typical gender paradigm linking men with the workplace and women with the home serves as a metaphor for social and familial disorder in Indonesian films. For similar conclusions on television's portrayal of career women, see also Saraswati Sunindyo, "Gender Discourse on Television."

45 S. Kartowijono, "Mari Bantulah Pekan Rumah Tangga!" p. 6. 
30 Suzanne Brenner

many other Astris out there" and that "You yourself, if you want to be honest, also have a hard time freeing yourself from this complex."

Although Femina aims at a middle- to upper-class urban readership, it provides a vision of womanhood that is essentially modern, and which would therefore be intended as a model, presumably, for all women in a nation where "development" is the primary goal. The fact that this "ideal" is not even imaginable for most women in this largely agrarian and relatively poor country seems to be of little concern to those who would promote it. Given all the choices for the modern woman offered by the New Order popular media, then, we need to ask what visions of modern womanhood were at the same time excluded. What possibilities were closed off, or deemed unrepresentable, by the media?

Indeed, when reading a magazine like Femina one could easily forget that there is a lower class or rural population in Indonesia. Missing from its pages is any hint that the urban, upper-middle-class standard of living depicted therein has not been reached by the vast majority of Indonesians. Most magazines make no mention of household servants, for example, despite the fact that they are ubiquitous in middle- and upperclass households. They are the women (and sometimes men) on whom the readers of Femina, Amanah, or Kartini rely to shop for food, cook their meals, clean their homes, look after their children, and free them up to pursue their careers and social activities, but they are absent from the advertisements, feature articles, stories, and advice columns in these magazines. None of the recipes in the food sections includes the directions, "Have your maid grind up six shallots, four cloves of garlic and three red chilis," even though that would be an accurate portrayal of the cooking process that goes on in most middle-class households. ${ }^{46}$ In my perusal of popular magazines from the 1990s I did come across one pointed reference to servants: a complaint about their absence from an Indonesian woman who had married a Japanese man and settled in Japan. She writes almost bitterly of the hardships that she endured because she could not afford any domestic help there: burning the food and the pots along with it (the implication being that she had never before done her own cooking); having to get up on cold winter mornings before her husband to make him breakfast; doing her own grocery shopping - "Imagine, I had to carry the baby on my back while my two hands were full of vegetables from the market, oh, it was awful! When the baby cried, I cried and cried, too ..."47 This account is from the Amanah article "Career Woman, Go Home"-might she have come to a different conclusion if she had had a housekeeper and a nanny taking care of her household for her, instead of having to do it all herself?

\section{Modernity and Morality}

The examples that I have cited thus far underscore the personal conflicts which, according to the popular print media, modernity creates for women (at least, middle-

\footnotetext{
46 I recall a women's social club (arisan) meeting that I attended at a Solo restaurant in the mid 1980s, at which a salesman for Electrolux tried to convince the ladies gathered there to buy a bulky, outdated (by American standards) food processor. The women viewed the demonstration with curiosity, but obviously had no intention of buying this contraption; all of them had servants at home who could do the same job much more cheaply.

47 "Wanita Karier, Pulanglah" (profile of Anni Iwasaki), Amanah 203 (April 18 - May 1, 1994), p. 17.
} 
class women) and their families. If this were seen as the full extent of the problem, there would probably not be too much public concern over how modernity affects women's behavior and how, in turn, women's behavior affects modernity. Were the issues considered merely to be of a personal nature, it is likely that they would receive less attention in the mass media than they do. But the personal and the domestic are never entirely separate from the public, and this is why women's behavior is scrutinized, sometimes criticized, and often constrained by public discourse.

In New Order rhetoric, the state, the family, and organized religion were often treated (especially, but not only, in state ideologies) as the three most sacred and fundamental institutions of modern Indonesian society, closely bound up with one another. Some people asserted that a threat to any one of them threatened the others, and by extension threatened the welfare of the whole society. Because women are so closely linked in public discourse with the family, their failures and indiscretions in the domestic sphere are often portrayed on a collective scale as menaces to the well-being of the nation at large. ${ }^{48}$ As an Indonesian saying quoted in Amanah goes, "Women are the pillars of the state. If the women are good, the state will also be good, but if the women are ruined, the state will be ruined as well." 49

Many women as well as men maintain that it is women's responsibility to safeguard the society's future through their own exemplary behavior and by seeing to it that their children receive a proper moral and religious upbringing. Examples of this are found in an article from Amanah, "Is the Rebelliousness of the Child the Failure of the Mother?"50:

... [A] mother, as the primary educator at home, is the first fortress in anticipation of the attacks on culture and from advanced technology, so that we don't find ourselves picking up the "garbage" of technology and Western culture. ... Because of this, in educating children, it is best to emphasize the aspect of morality. 51

The article quotes one woman in a Mother's Day (Hari Ibu) commemoration:

"The influences of modernization certainly can't be avoided. But we must be on guard against all of those influences so that our identity as God's servants remains firm. The problems of scientific and technological progress, and the flow

\footnotetext{
48 As part of its program to promote religion, especially Islam (always warning of the dangers of atheism, which raised the specter of communism and ultimately political and social chaos), the New Order state sponsored local pengajian (gatherings for recitation of the Qur'an which include a sermon or textual exegesis) at the neighborhood level in order to foster religious knowledge and practice among women in particular. The pengajian that I attended in Solo in the 1980s often featured sermons that focused on women's responsibility for their families' moral welfare and religious education. Men were usually absent from the neighborhood pengajian, except for the host (if it were held at someone's home) and the muballigh (preacher) who gave the sermon. Always implicit or explicit in the message was that the failure of the mother to impart the right values to her family had the potential to harm not only the members of her family, but also the entire nation and the umat Islam, extended Muslim community.

49 "Wanita adalah tiang negara, jika wanitanya baik, baik pula negara itu, tapi jika kaum wanitanya rusak, maka akan rusak pula negara itu." Quoted in Amanah 142 (December 13-26, 1991), p. 10.

50 "Durhaka Anak, Kegagalan Ibu?" (Is the rebelliousness of the child the failure of the mother?) Amanah 142 (December 13-26, 1991), pp. 10-14C.

51 Ibid., p. 11.
} 
of information that is so very rapid, are aspects of human development. Because of that, we need a corrective attitude [sikap korektif] so that we aren't washed away by the current," explained Mrs. Bayyinah, the Principal of the State Home Economics School of Yogyakarta.

"Kartini became known as someone who broke through the isolation of women, and commemorating Mother's Day means restoring the role and prestige of mothers. Mothers will continue to be honored and respected as long as they remain on a correct base, both as the primary educators in the family and as the preservers of the nation's culture." 52

Here, the connections between a woman's role as mother and her roles as citizen of the nation/guardian of its traditions ("preserver of the nation's culture") and as devoted follower of religion ("God's servant") are made explicit. "Preserver of the nation's culture" (pelestari budaya bangsa) means the protector of what are construed to be indigenous, rather than imported (i.e., Western), values and behavioral norms. A woman can only continue to occupy these roles, however, if she herself "remains on a correct base" as a model of morality and propriety.

Women's collective behavior, then, tends to be viewed as a barometer for measuring the moral climate of the nation. The rapid social change that Indonesia has experienced over recent decades has opened up pathways to women that were not open to them before, as I have already stressed. But, as might be expected, conservative reactions have also emerged against some of the liberties that women are perceived to have acquired. Certain changes in women's behavior are held in conservative views to be indicators not of progress, but of the moral degeneration of the nation. Mass-market books on Islam with titles like Where Are Our Women Being Led? (Dibawa kemana Wanita Kita), 53 some of which are translations of books from Saudi Arabia, Iran, or elsewhere in the Islamic world, argue that Muslim women have been led astray by Western ideas that claim to emancipate women but actually enslave them. Women's moral misguidance is a figure for, and at the same time depicted as a potential result of, the dangers that Indonesian society (or, more inclusively, Muslim society or "Eastern" society) faces if it adopts a "bad" style of modernity from the West:

Western women have gone too far in denying their female nature [kodrat kewanitaan], by seeking equal rights with men in every matter. They have forgotten that being a housewife is something that is most noble and special and which should be considered the greatest honor. Women who just waste most of their lives by amusing themselves and fooling around with men, neglecting their household affairs and their work, are unable to care for their children and do not wish to live peacefully in their households-these are things that they do intentionally in order to find an outlet for their passions. In truth, a modern woman is a woman who is liberated in certain matters, but limited and restrained within certain bounds. She is highly educated, intellectual, greatly values time and does not play around, throwing about her money and her desire. Women

\footnotetext{
52 Ibid., p. 14A.

${ }^{53}$ Muhammad Quthub, Dibawa kemana Wanita Kita? (Where are our women being led?) (Jakarta: Pustaka Al Kautsar, 1991).
} 
who deserve respect from men are women who are capable of proving themselves as good women, good wives and good mothers. The respect that is shown by Western society toward women is nothing but a lie, just so they can give rein to their desires and have intercourse freely. They support freedom for women merely because they feel lucky to be able to enjoy women [sexually] without a single obstacle. ${ }^{54}$

Not surprisingly, "immoral behavior" for women, as in the passage just cited, usually refers to their sexual activities outside of marriage. Articles about prostitution, extramarital affairs, and premarital sex in Indonesia appear with predictable regularity in newspapers, tabloids, and magazines, under attention-grabbing rubrics like "Sex Transactions in the Graveyard" (Transaksi Seks di Kuburan), "Exchange Behind Bamboo Blinds" (Bursa di Balik Krei Bambu), and "When Sexual Norms are Pushed Aside" (Bila Norma Seks Ditepiskan). ${ }^{55}$ Although many of these articles are of a sensational nature, intended more to sell copies at the newsstand than as serious commentary on the condition of Indonesian society, they provide ample fuel for those who wish to point to the decline in morality resulting from modernization.

Despite the fact that men as well as women are implicated in the sexual activities being discussed, the greatest outcry is directed at women's rather than men's licentious behavior. When men have extramarital affairs, the typical response is, more or less, "boys will be boys," or, as the author of "Understanding Real Men" puts it, "it is indeed part of men's character to want to have intimate relations with many women." 56 Men's sexual behavior is rarely seen as a matter for genuine public concern; whether or not it should even be the family's concern is open to some debate. The article "Understanding Real Men" quotes an "understanding" female entrepreneur on the subject of her husband's extramarital activities: "From my perspective, as soon as he steps out the front door of this house, I consider whatever he does to be no longer the concern of this family. It's his own business." 57 It would be almost unimaginable for any Indonesian magazine to cite a similar statement made by a man about his wife; the notion that a wife's sexual behavior outside the home is not her husband's business would be virtually unthinkable. Female sexuality, far more than men's, is an issue that crosses both private and public domains. In public discussion, ranging from statements made by government officials, to the sermons of religious leaders, to articles in cheap tabloids and magazines, women's sexuality and morality have been treated as matters for everyone's concern, with repercussions for the future of the entire society.

\footnotetext{
${ }^{54}$ Nazhat Afza and Khurshid Ahmad, Mempersoalkan Wanita (On the problem of women) (Jakarta: Gema Insani, n. d.), pp. 18-19.

55 These articles appeared respectively in Liberty 1779 (August 1-15, 1992), Matra 72 (July 1992), and Panji Masyarakat 680 (April 11-20, 1991).

56 "Memahami Pria-Pria Sejati," pp. 38-39.

57 Ibid., p. 39. This may not be an uncommon sentiment. When I was conducting fieldwork in Solo, a middleaged woman remarked, when discussing the issue of men's infidelity, "My mother used to say to me, 'when he's at home, he's your husband, but when he's outside the home, think of him as someone else."' For a discussion of men's and women's extramarital relations in the Javanese context, see my Domestication of Desire, esp. chapter 4, and Hildred Geertz, The Javanese Family: A Study of Kinship and Socialization (Glencoe, IL: Free Press, 1961).
} 
34 Suzanne Brenner

While complaints about women's behavior are launched most vigorously from staunchly conservative Islamic quarters-which does not, however, include all Muslims-they are also voiced by those whose interests are more secular and "cultural." A male university lecturer writing in Matra (Dimension), the self-styled "Magazine of Trends for Men," observes that in the culture of the traditional Javanese aristocracy (budaya priyayi),

women as housewives [ibu rumahtangga] stayed at home more, educating and raising their children in the traditional way. Ethical values, respect, were always planted harmoniously [in children] by these mothers. The more open the role of housewife has become, the more negative effects have surely resulted. Quite a few cases of housewives being unfaithful, who according to the ideals of Javanese culture should be faithful to their husbands, have occurred in Solo la center of the Javanese nobility].

But society's control over these matters is still strong. People consider unfaithfulness to be something forbidden and not to be admired. The increased influence of modern culture [budaya modern] on the lifestyle of the city will loosen society's control, as is already apparent in the big cities of Indonesia. In the end, the values that have already been established will change in keeping with changes in society and changes in culture. ${ }^{58}$

Ultimately, mainstream opinions aired in the media about proper behavior for women are distinguishable from strict Islamic views more by degree than by substantive differences in content. While Islamic fundamentalist pronouncements tend to be the harshest in their assessment of women's "immoral" behavior and its damaging effects on society, common views expressed in the mass media also lean toward conservative judgment about what constitutes acceptable or unacceptable behavior for women and what the implications are of women's actions for the future of the society. The broad moral code that was dominant in New Order society and continually reaffirmed by the popular media, religious institutions, law, and government policy ultimately placed a high value on the control of women's behavior in general and of their sexuality in particular. As Gusti Kanjeng Ratu Hemas, the wife of the Sultan of Yogyakarta, wrote in her book Indonesian Women: A Conception and Obsession:

Indonesian society still distinguishes between men's and women's sexual behavior. The norms that are in effect in society continue to place men in a higher position. Men have the tendency to be polygamous. Through these norms, the moral sanctions for men who have sex outside of marriage are less severe than they are for women. In contrast, a woman who believes in the notion of free sex, or who becomes a mistress or a second wife will be penalized by the norms of society..$^{59}$

\footnotetext{
58 Suyatno Kartodirdjo, “Gaya Hidup dan Istri Simpanan” (Lifestyles and mistresses), Matra 72 (July 1992), p. 69.

${ }^{59}$ Gusti Kanjeng Ratu Hemas, Wanita Indonesia: Suatu Konsepsi dan Obsesi (Indonesian women: A conception and obsession) (Yogyakarta: Liberty, 1992), p. 102.
} 


\section{Public Intimacy in the New Order}

What are we to make of this obsession with women's sexuality and morality, with their fittingness to serve as mothers of their own children and, by extension, of the next generation of Indonesian citizens? Why have women figured so prominently in media representations of the choices and dangers of modernity? And why, finally, were the private affairs of the household turned into the public affairs of the nation in the New Order?

We might look to other places besides Indonesia for insight into these questions. In The Queen of America Goes to Washington City (1997), Lauren Berlant argues that the rise of conservatism during the Reagan years in the United States (and continuing well beyond them) brought about a situation in which, as she puts it, "a familial politics of the national future came to define the urgencies of the present." 60 The rise of the right, according to Berlant, ushered in an era in which the personal and political were collapsed into "a world of public intimacy," 61 as conservative agendas focusing on family values, personal morality, reproduction, and sexuality pushed aside a genuine collective politics in favor of a privatized notion of citizenship. When public discourse is focused on such private issues as abortion, homosexuality, and the supposed breakdown of the family, the collective gaze is directed away from basic social issues-including economic inequality and the smoldering class war, racism, and the exploitation of workers under capitalist production-thereby "substituting patriotic images of a generic familial good life ... for images of a world organized around the economic contexts in which specific people live."62 Because those who would orchestrate the national narratives in the present are always concerned with securing control over the national future as well, reproduction and the family are especially sensitive political issues. As she sees it, the process of turning people into national subjects is surrounded by anxieties which reveal that "the hegemonic form of national culture is fragile and always in the process of being defined" even when it appears to have a fixed, essential character. 63

Berlant's work is useful for understanding the significance of recurrent discourses on women and the family in the popular media of the New Order. In its efforts to foster its own power, the New Order regime engaged in a delicate balancing act. It worked tenaciously on the one hand to maintain stability, the comfortable sense that everything would be taken care of as long as the nation remained on a firm moral footing and accepted the authority of the state and its legitimizing ideology, Pancasila. On the other hand, in order to retain its ideological power an authoritarian regime must continually reestablish a climate of national crisis, raising the fear of an unseen danger, an impending chaos, that threatens to descend upon the nation if stability is not maintained. Real crises of citizenship-the widening gap between rich and poor, the political hegemony of a single ethnic group in a multiethnic nation, the deep-seated corruption of bureaucrats at every level of government, and the stifling of all forms of

\footnotetext{
${ }^{60}$ Lauren Berlant, The Queen of America Goes to Washington City: Essays on Sex and Citizenship (Durham, NC: Duke University Press, 1997), p. 1.

61 lbid.

62 Ibid., p. 97.

63 Ibid., p. 56.
} 
dissent-were suppressed and displaced through national narratives of moral crisis in the family, of communists and other antinational figures lurking behind every corner, and of the dangers of Indonesia's citizens emulating either the hedonistic (read: democratic?) West or the "fanatical" Muslims of Iran and other Islamic countries.

The New Order, in short, effectively created its own world of public intimacy. By turning public scrutiny to the private sphere, by making the moral character and behavior of women in particular a focus of concern and debate, attention could be diverted away from the issues that might, and should, give rise to a real collective politics. The open and ultimately violent politics of the Sukarno period gave way to a climate in which even the word "politics" took on a forbidden tone. Tensions and anxieties that accompanied political repression, rapid and uneven modernization, and economic inequality and instability were displaced onto the figures of woman and the family. In New Order representations, the happy, middle-class family came to stand for a generic Indonesian moral and social order; the moral integrity of the family was portrayed as an issue that transcended all social, cultural, or economic differences. In her roles as mother and wife, the New Order woman signified the comforts of stability as well as of the dangers that threatened the nation should that stability break down. Control over the national future, it seemed, could be gained through control over the family and over the woman who was so closely tied to it in public discourse and media representation.

This "conversion of gender to nationality,"64 to use Berlant's phrase, has occurred in many other national contexts, and is particularly visible under right-wing regimes. Afsaneh Najmabadi has noted, for example, that both the state and oppositionist groups in Iran, with their respective political agendas, have shared a concern with establishing and enforcing societal norms for women's behavior. ${ }^{65}$ From the 1960 s on, women who were seen as too Westernized, or "westoxicated," were considered by both Islamic and secular opponents of the pre-1979 regime as corrupters of the nation's morals and the tools of Western imperialists. After the Islamic revolution women became, even more, the focus of social control; modest behavior for women, which was expanded to include veiling and segregating them from men, was deemed essential for the moral health of the nation and its ability to keep imperialist powers at bay.

The effort to control women's behavior and sexuality for the ostensible benefit of the society's future can also be seen in an example from Singapore, where in 1983 Prime Minister Lee Kuan Yew accused women-in particular, educated, middle- and upper-class women-of endangering the nation's future by refusing to reproduce at a satisfactory rate. ${ }^{66}$ Lee and others in his government were alarmed at statistics which showed that less-educated women in Singapore (who happened to be mostly lowerclass Malays and Indians rather than the better-off Chinese) were having a much higher number of children on average than educated, professional (mostly Chinese) women.

64 Ibid., p. 100.

65 Afsaneh Najmabadi, "Hazards of Modernity and Morality: Women, State and Ideology in Contemporary Iran," in Women, Islam and the State, ed. Deniz Kandiyoti (Philadelphia: Temple University Press, 1991), pp. 48-76.

${ }^{66}$ Geraldine Heng and Janadas Devan, "State Fatherhood: The Politics of Nationalism, Sexuality, and Race in Singapore," in Andrew Parker et al., ed., Nationalisms and Sexualities, pp. 343-64. 
The government subsequently waged a strident campaign, aided by the mass media, to argue and almost to insist that educated women take it as their patriotic duty to have children - the more the better. Geraldine Heng and Janadas Devan make a persuasive case that "an unruly, destabilizing, and irresponsible feminine sexuality" was considered the cause of the collapse in the social and economic order which, Lee feared, threatened in the decades ahead if demographic trends continued on in the same pattern. "Chaos, in this prophecy of national disaster," Heng and Devan propose, "was visualized as the random interplay of excess and deficiency among female bodies, which, left unregulated, would produce disabling, ungovernable, and unsafe equations of class and race." 67

Ideas about proper behavior for women are always intimately attached to political agendas and to notions of social control and order. The "problem of women" in Indonesia and elsewhere is that no nation can forge ahead with its plans for modernity, no matter what form that modernity is envisioned as taking, without fully incorporating women into the endeavor. At the same time, however, the image of a domesticated woman-one who maintains, all at once, the family, continuity with the past (real or imagined), the moral order and the status quo-is a central image of social order and stability. The uncertainty of modernity always threatens to disrupt the social and political order, and the picture of uncontrollable women-wantonly sexual; reversing the "proper" order of things by dominating males instead of being dominated by them; shirking their "natural" roles as wives and mothers-is the very image of modernity gone awry. In the end, the Suharto regime's determined efforts to control the national future crumbled under the pressure of an economic disaster rather than a moral crisis of unmanageable women. But it remains to be seen whether the world of public intimacy that the regime created will disintegrate as well or continue into the future as a legacy of the New Order.

${ }^{67}$ Ibid., pp. 345-46. 
